\title{
THE REQUIRED ENERGY FOR CUTTING OPERATION OF SOME FIELD CROP RESIDUES
}

\author{
Megahed, S. S. ${ }^{1}$; Abdel-Salam, M. F. ${ }^{2}$; EINono, M. A. ${ }^{2}$
}

\section{ABSTRACT}

The performance of an experimental crop residues cutting machine has been investigated in this work in order to evaluate the energy requirements for cutting operation of three different crop residues (cotton stalks, corn stalks, and rice straw). The effect of cutting drum speed, knife edge angle and clearance distance on the machine productivity, fuel consumption, required power, specific consumed energy, cutting efficiency and the economical costs at optimum machine operation were, also, studied. The machine evaluated at five cutting drum speeds 1200, 1300, 1400, 1500 and $1600 \mathrm{rpm}(8.29,8.98,9.68,10.37$ and $11.06 \mathrm{~m} / \mathrm{s})$; five knife edge angles $\left(20^{\circ}, 25^{\circ}, 30^{\circ}, 35^{\circ}\right.$ and $\left.40^{\circ}\right)$; and five clearance distance $(1,2,3,4$ and $5 \mathrm{~mm})$. The results showed that the maximum cutting efficiency for cotton stalks $\left(20.56 \% M_{c w b}\right)$, corn stalks $(25.64 \%$ $\left.M_{c w b}\right)$, and rice straw $\left(14.8 \% M_{c w b}\right)$ were $67.7 \%, 47.59, \%$ and $62.75 \%$, respectively, at $1600 \mathrm{rpm}$ cutting drum speed, $20^{\circ} \mathrm{knife}$ edge angle, and Imm clearance distance.

Keywords: Cutting machine; crop residues; energy requirements; cutting efficiency.

\section{INTRODUCTION}

$\mathrm{F}$ Tield crop residues are organic materials which are produced by products from harvesting and processing of agricultural crops. cotton, wheat, corn or maize and rice. Large quantities of crop residues are produced annually in Egypt. They reached about 18.7 million ton per year and the national income might be increased with 1.6 billion LE/year if we try to recycle it (El-Berry et. al., 2001 and Awady et. al. 2001, cited by El-Hanfy and Shalby, 2009).

\footnotetext{
${ }^{1}$ Graduate student, Fac. of Agric., Ain Shams University, Cairo, Egypt. ${ }^{2}$ Agric. Eng. Dep., Fac. of Agric., Ain Shams University, Cairo, Egypt.
} 
The area of cotton crop cultivation produced about $9 \%$ of the total amount of the crop residues per year. The total cultivated area of rice is approximately 1.46 million feddan which is considered one of the most widely cultivated cereal crops in Egypt. It is produced about 3.28 million tons of rice straw per year according to the Ministry of Agriculture and land Reclamation, 2006. Consequently, the increase of field crop residues will cause a serious problem facing the agricultural producers because they are burnt or left to decompose, but most of these current practices are not working well because of wasting time, money, energy, and polluting the environment; However, there are many efficient and simplest methods of using the field crop residues, and all of these methods depend on the cutting process which may be chopping or shredding of the field crop residues for size reduction to be suitable for various uses such as food for farm animals, compost to substitute the chemical fertilizers and improve the agricultural soil, traditional source of domestic fuel in rural areas, and it can, also, be used in manufacturing. Taiab and Imbabi (1995) proved that the cutting energy and force requirements increased with increasing the stem diameter. Habib et. al. (2002) found that the predominant parameters affecting the cutting process performance of agricultural material were related to the cutting tool, machine specifications and plant material properties. Suliman et. al. (2010) studied some engineering factors concerning the performance of the affecting tool in crop residues shredder. Their results indicated that cutting drum speed, knife edge angle, and clearance distance are affected the cutting efficiency, fuel consumption and the shredder production. They, also, mentioned that the proper selection of new material leads to decrease the sharp edge angle of modified knives to $20^{\circ}$ degree without deformation.

The present work aims to investigate and evaluate the performance of an experimental crop residues cutting machine that is owned by the Aried Land and Agricultural Research and services center, Faculty of Agricultural, Ain Shams University to determine the energy requirements for cutting operation of three different crop residues which are cotton stalks, corn stalks and rice straw. It also discusses: 
1- The effect of cutting drum speed, knife edge angle and clearance distance on machine productivity, fuel consumption, required power, specific consumed energy and cutting efficiency.

2- The economical costs at optimum machine operation.

\section{MATERIALS AND METHODS}

The experiments of this work were conducted in Agric. Eng. Dept., Fac. of Agric., Ain Shams Univ. in 2012. The following material and methods were used:

\section{3-1-Crop residues cutting machine:}

An experimental cutting machine of crop residues was manufactured by Daeheuug machine ery Co., LTD, Seoul, Korea. It is illustrated schematically in Fig. (1) and photographed in Fig. (2). It is owned by the Arid Land and Agricultural Research and Services Center, Fac. of Agric., Ain Shams Univ. It consisted of the following main components:

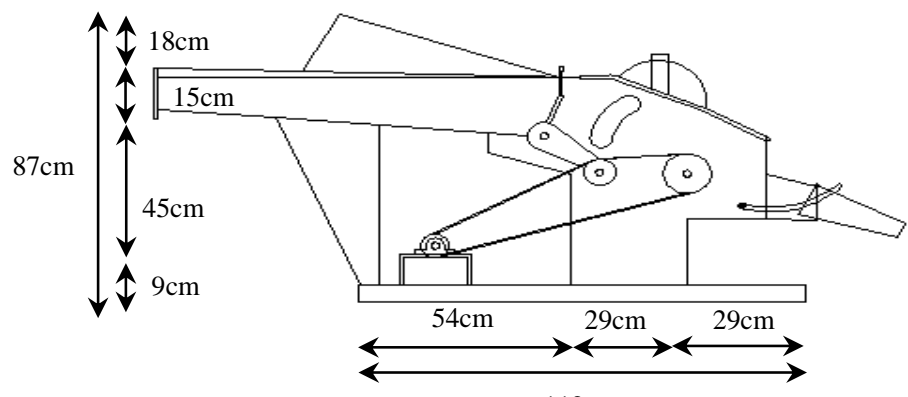

$112 \mathrm{~cm}$

Fig. (1): Schematic diagram of crop residues cutting machine.

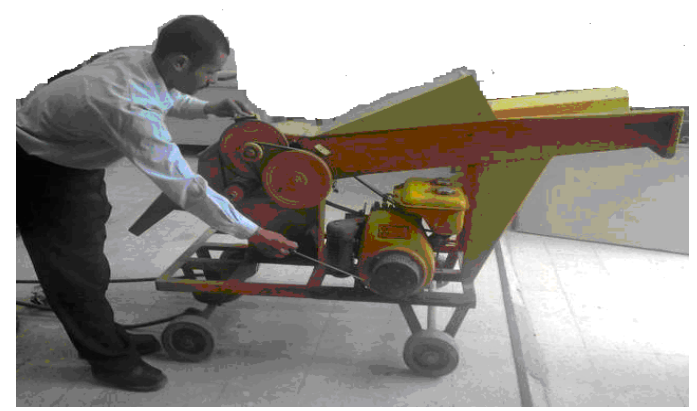

Fig. (2): Photograph of crop residues cutting machine. 


\section{3-1-a- Engine:}

A single cylinder, four stroke, air cooled, spark-ignition engine DLS' 267 $\mathrm{CC}$

Rated HP: 5/3600 rpm

Max. HP. 6/4000 rpm

\section{3-1-b- A rotary cutter drum:}

It has four knives rotating in vertical plane. The drum has $12 \mathrm{~cm}$ outer diameter, $6 \mathrm{~cm}$ inner diameter, and $17 \mathrm{~cm}$ length.

\section{3-1-c- Knives}

Four knives are distributed on the periphery surface of the cutter drum, they are made of steel. The knife dimensions are $17 \mathrm{~cm}$ length, $4.5 \mathrm{~cm}$ width and $6 \mathrm{~mm}$ thickness. Five groups of knives were fabricated with different edge angles $\left(20,25,30,35\right.$ and $\left.40^{\circ}\right)$ to study the effect of the knife edge angle on the machine performance.

\section{3-1-d- A stationary countershear}

A stationary countershear $(17 \mathrm{~cm}$ length, $10 \mathrm{~cm}$ width and $6 \mathrm{~mm}$ thickness) is fixed to the supporting machine frame. So, the crop material is sheared as the knife passes over the countershear.

\section{3-1-e. Power transmission:}

The power is transmitted from the engine to the rotary cutter drum by means of a set of pulleys and V-belts, as shown in fig. (1).

\section{3-2- Moisture content of the crop residues:}

The moisture content of the crop residues was determined using the standard oven methods. Samples of crop residues were weighted (using an electrical balance, $0.01 \mathrm{~g}$ accuracy) and dried in an oven at $103^{\circ} \mathrm{C}$ for 24h. The moisture content for each sample was calculated on wet basis using the following equation (Henderson and Perry, 1981):

$$
M_{c w b}=\frac{M_{b}-M_{a}}{M_{b}} \times 100
$$

Where:

$\mathrm{M}_{\mathrm{b}}$ and $\mathrm{M}_{\mathrm{a}}$ are the masses of the sample ( $\mathrm{g}$ ) before and after drying, respectively.

$\mathrm{M}_{\mathrm{cwb}}$ is the moisture contents (\%) based on wet bases. 


\section{3-3- The machine productivity:}

Three samples (about $3 \mathrm{Kg}$ each) were taken from each air-dried crop residues. Each sample was fed to the machine. The output of cutting material was collected and the corresponding time was recorded with the help of a digital stop watch of 0.1 second accuracy. Then the output material was weighted, and the average machine productivity was calculated as.

$$
P_{\text {rod }}=\frac{\text { machine output }(g)}{\text { Corres ponding time }(s)} \times \frac{3600}{10^{6}} \longrightarrow
$$

Where: $\quad \mathrm{P}_{\text {rod }}$ is the machine productivity (ton/h)

\section{3-4- Fuel consumption:}

Fuel consumption per unit time was determined by measuring the volume of the consumed fuel during the experiment time. It was calculated as the following:

$$
\mathrm{F}_{\mathrm{c}}=(V / t) \times 3.6
$$

Where:

$\mathrm{F}_{\mathrm{c}}=$ Fuel consumption rate, $1 / \mathrm{h} ; \mathrm{V}=$ Volume of consumed fuel, $\mathrm{cm}^{3}$; and $\mathrm{t}=$ Time of the experiment, $\mathrm{S}$.

\section{3-5- Power requirements:}

Engine power that was required to drive the cutting machine of crop residues was estimated using the following formula (Embaby, 1985):

R.E.P. $=\left(\mathrm{F}_{\mathrm{c}} \times \frac{1}{3600}\right) \rho_{f} \times$ L.C.V $\times 427 \times \eta_{\mathrm{th}} \times \eta_{\mathrm{m}} \times \frac{1}{75} \times \frac{1}{1.36} \longrightarrow$

Where :

R.E.P $=$ Power requirements from fuel consumption, $\mathrm{Kw} ; \mathrm{F}_{\mathrm{c}}=$ Fuel consumption rate; $\mathrm{L} / \mathrm{h} ; \rho_{\mathrm{f}}$. Density of the fuel, $\mathrm{Kg} / \mathrm{L}$ (assumed $0.85 \mathrm{Kg} / \mathrm{L}$ for gasoline; L.C.V.= Lower calorific value of fuel; Kcal/Kg (assumed $10000 \mathrm{Kcal} / \mathrm{Kg}$ for gasoline); 427 = Thermo-Mechanical equivalent; $\mathrm{Kg}$ $\mathrm{m} / \mathrm{kcal}$ ); $\eta_{\mathrm{th}}=$ Thermal efficiency (assumed to be $35 \%$ for gasoline engine; and $\eta_{\mathrm{m}}=$ Mechanical efficiency (assumed to be $80 \%$ ).

\section{3-6- Specific consumed energy:}

The specific consumed energy was calculated using the following equation: 


$$
\text { S.C.E. }=(\text { R.E.P. }) / P_{\text {rod }}
$$

Where:

S.C.E. $=$ Specific consumed energy; $k W h /$ Ton

R.E.P = Required engine power; $\mathrm{kW}$

$P_{\text {rod }}=$ Machine productivity; Ton $/ \mathrm{h}$.

\section{3-7- Cutting efficiency:}

Cutting length of final machine output is a critical factor of cutting process for producing compost and forage. The suitable cutting length $\left(\mathrm{L}_{\mathrm{c}}\right)$ should be in the range of $0<\mathrm{L}_{\mathrm{c}}<50 \mathrm{~mm}$ (Habib et al., 2002), and the cutting efficiency could be calculated as:

$$
\delta_{c}=S_{a} / S_{b} \times 100
$$

Where :

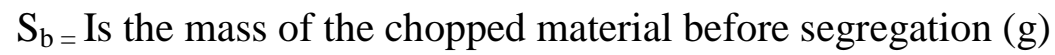

$\mathrm{S}_{\mathrm{a}=}$ Is the mass of chopped material (after segregation) of cutting length,

$\mathrm{O}<\mathrm{L}_{\mathrm{c}}<50 \mathrm{~mm}(\mathrm{~g})$.

$\delta_{\mathrm{c}=}$ Is the cutting efficiency $(\%)$.

Therefore, a sample was taken from the final product and weighted, to find the mass of $S_{b}$, than it segregated using standard sieve (50 mm mesh) and the mass of $S_{a}$ was determined. Finally, equation (3) was applied.

\section{3-8- Cost estimation}

The economical costs per hour of operation of the crop residues cutting machine was estimated using the following expression that was developed by Awady (1978) as:

$\mathrm{T}_{\mathrm{C}}=[C / h] \times[1 / L+i / 2+t+r]+\left[1.2 \times F_{c} \times f\right]+[m / 144] \longrightarrow$

The following assumptions were used:

$\mathrm{C}=$ The initial price of the crop residues cutting machine $=4000 \mathrm{LE}$.

$\mathrm{h}=$ Work hours per year $=3000 ; \mathrm{l}=$ Life expectancy $=15$ years;

$\mathrm{i}=$ Ratio of annual interest $=0.1 ; \mathrm{t}=$ Ratio of annual taxes $=0.01 ; \mathrm{r}=$ Ratio of annual repairs and maintenance $=0.035 ; F_{c}=$ Fuel consumption at the best machine cutting efficiency; L/h (measured); $\mathrm{F}=$ Fuel price; 1.1 LE/L; and $m=$ Operator monthly salary $=900 \mathrm{LE}$.

The operator monthly average working hours $=144$

$\mathrm{T}_{\mathrm{c}}=$ Cost per hour of operation; $\mathrm{LE} / \mathrm{h}$ 


$$
\text { Cost per ton }=\frac{T_{C}\left(\frac{L E}{h}\right)}{P_{\text {rod }}\left(\frac{T o n}{h}\right)}=\quad\left(\frac{L E}{T o n}\right)
$$

\section{RESULTS AND DISCUSSION}

Results presented in this section were obtained for three different types of crop residues (cotton stalks, corn stalks and rice straw). For each type, the cutting machine was tested to determine the machine productivity, fuel consumption, required power, specific consumed energy and cutting efficiency. The machine was evaluated at : a) five cutting drum speed $(1200,1300,1400,1500$ and $1600 \mathrm{rpm}$ or $8.29,8.98,9.3 .68,10.37$ and $11.06 \mathrm{~m} / \mathrm{s})$; b) five clearance distance $(1,2,3,4$ and $5 \mathrm{~mm})$; and c) five knife edge angle $\left(20^{\circ}, 25^{\circ}, 30^{\circ}, 35\right.$ and $\left.40^{\circ}\right)$.

\section{3-1- Cotton Stalks}

\section{3-1-1- Machine Productivity:}

Fig. (3) shows that machine productivity increased with increasing the cutting drum speed. It increased by an average $24.24 \%$ with increasing the cutting drum speed from 1200 to $1600 \mathrm{rpm}$, at $20^{\circ} \mathrm{knife}$ edge angle, $1 \mathrm{~mm}$ clearance distance, and $20.56 \% \mathrm{M}_{\mathrm{cwb}}$. They, also, show that productivity decreased with an average $40.48 \%$ with increasing the knife edge angle from $20^{\circ}$ to $40^{\circ}$ at $1600 \mathrm{rpm}$ cutting drum speed and $1 \mathrm{~mm}$ clearance distance. This may be due to difficulty of the penetration into the material with increasing the knife edge angle (Suliman et.al.,2010). It can be, also, noticed that there was slight increase of the machine productivity with increasing the clearance distance. It increased by an average $2.94 \%$ with increasing the clearance distance from 1 to $5 \mathrm{~mm}$ at $1600 \mathrm{rpm}$ cutting drum speed, $20^{\circ} \mathrm{knife}$ edge angle, and $20.56 \%$ $\mathrm{M}_{\mathrm{cwb}}$. Maximum and minimum rate of machine productivity at $20.56 \%$ $\mathbf{M}_{\mathrm{cwb}}$ are given in Table (1).

Table (1): Max. and Min. rate of machine productivity, for cotton stalks.

\begin{tabular}{|c|c|c|c|}
\hline \multirow{2}{*}{$\begin{array}{c}\text { Productivity } \\
\text { (ton/h) }\end{array}$} & $\begin{array}{c}\text { Cutting drum } \\
\text { speed (rpm) }\end{array}$ & $\begin{array}{c}\text { Knife edge } \\
\text { angle }\end{array}$ & $\begin{array}{c}\text { Clearance } \\
\text { distance }(\mathrm{mm})\end{array}$ \\
\hline Max. $=0.0476$ & 1600 & $20^{\circ}$ & 5 \\
\hline Min. $=0.0195$ & 1200 & $40^{\circ}$ & 1 \\
\hline
\end{tabular}



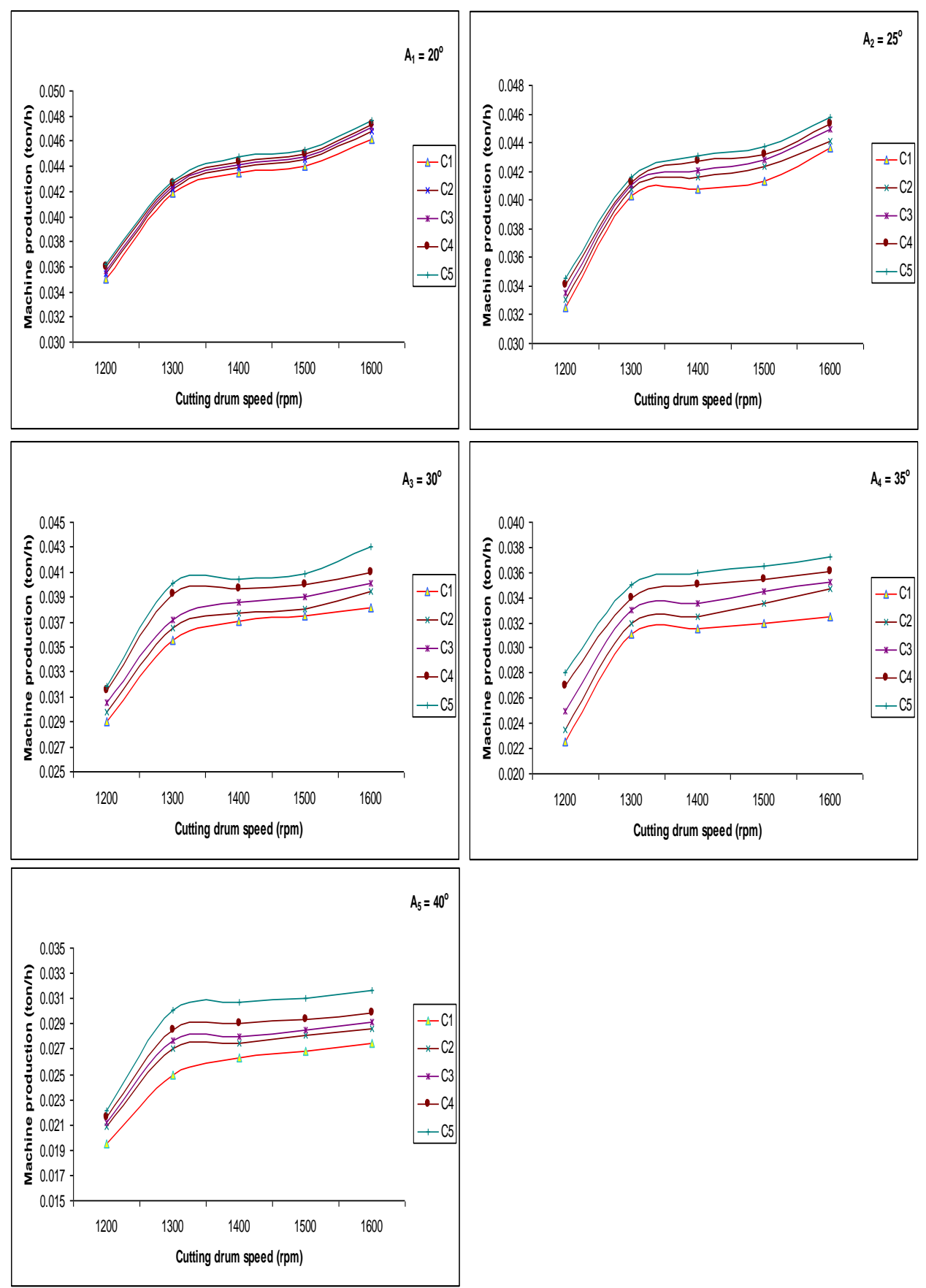

Fig (3): Machine productivity as a function of cutting drum speed at different (A) knife edge angle $\left(20^{\circ}, 25^{\circ}, 30^{\circ}, 35^{\circ}\right.$ and $\left.40^{\circ}\right)$, (C) clearance distance $(1,2,3,4$, and $5 \mathrm{~mm})$, and $20.56 \% \mathrm{M}_{\mathrm{cwb}}$ for cotton stalks. 


\section{3-1-2-Fuel consumption:}

Results illustrated in Fig. (4) show that fuel consumption increased with increasing the cutting drum speed. It is increased by an average $66.67 \%$ with increasing the cutting drum speed from 1200 to $1600 \mathrm{rpm}$ at $20^{\circ}$ knife edge angle, $1 \mathrm{~mm}$ clearance distance, and $20.56 \% \mathrm{M}_{\mathrm{cwb}}$ this may be due to increasing the number of cuts per unit time by increasing the cutting drum speed which required increasing in fuel consumption (Sluman et.al. 2010). It is, also, clear the fuel consumption increased with increasing knife edge angle. It increased by an average $16.67 \%$ with increasing knife edge angle from $20^{\circ}$ to $40^{\circ}$ at $1600 \mathrm{rpm}$ cutting drum speed, $1 \mathrm{~mm}$ clearance distance, and $20.56 \mathrm{M}_{\text {cub }}$. This may be due to increasing the friction forces (main resistance for cutting) on the knife edge with increasing the knife edge angle. Results also, showed that full consumption increased slightly with increasing the clearance distance. It increased by an average $6.25 \%$ with increasing the clearance distance from 1 to $5 \mathrm{~mm}$ at $20^{\circ} \mathrm{knife}$ edge angle, $1600 \mathrm{rpm}$ cutting drum speed, and $20.56 \% \mathrm{M}_{\mathrm{cwb}}$.

The maximum and minimum rates of fuel consumption are given in table (2).

Table (2): Max. and Min. rate of fuel consumption, for cotton stalks.

\begin{tabular}{|l|c|c|c|}
\hline \multirow{2}{*}{$\begin{array}{c}\text { Fuel } \\
\text { consumption } \\
(\mathrm{L} / \mathrm{h})\end{array}$} & $\begin{array}{c}\text { Eutting drum } \\
\text { speed (rpm) }\end{array}$ & $\begin{array}{c}\text { Knife edge } \\
\text { angle }\end{array}$ & $\begin{array}{c}\text { Clearance } \\
\text { distance }(\mathrm{mm})\end{array}$ \\
\cline { 2 - 4 } & 1600 & $40^{\circ}$ & 5 \\
\hline Max. $=0.48$ & 1200 & $20^{\circ}$ & 1 \\
\hline Min. $=0.12$ & &
\end{tabular}

\section{3-1-3- The required power:}

Data for the required power (kw) in Fig. (5) show similar trend to that obtained previously for the fuel consumption where the required power increased with increasing the cutting drum speed, knife edge angle, and the clearance distance. It increased by an average 50.8\% with increasing the cutting drum speed from 1200 to $1600 \mathrm{rpm}$ at $30^{\circ} \mathrm{knife}$ edge angle, $1 \mathrm{~mm}$ clearance distance, and $20.56 \% \mathrm{M}_{\mathrm{cwb}}$. It, also, increased by an average $33.3 \%$ with increasing the knife edge angle from $20^{\circ}$ to $40^{\circ}$ at $1400 \mathrm{rpm}$ cutting drum speed, and $1 \mathrm{~mm}$ clearance distance. The required 
power increased slightly by an average $6.21 \%$ with increasing the clearance distance from 1 to $5 \mathrm{~mm}$ at $20^{\circ} \mathrm{knife}$ edge angle and $1600 \mathrm{rpm}$. Maximum and minimum required power is given in Table (3).

Table (3): Max. and Min. required power, for cotton stalks.

\begin{tabular}{|c|c|c|c|}
\hline \multirow{2}{*}{$\begin{array}{l}\text { Required Power } \\
\qquad(\mathrm{kW})\end{array}$} & \multicolumn{3}{|c|}{ Engineering factors } \\
\hline & $\begin{array}{l}\text { Cutting drum } \\
\text { speed (rpm) }\end{array}$ & $\begin{array}{c}\text { Knife edge } \\
\text { angle }\end{array}$ & $\begin{array}{c}\text { Clearance } \\
\text { distance }(\mathrm{mm})\end{array}$ \\
\hline Max. $=1.328$ & 1600 & $40^{\circ}$ & 5 \\
\hline Min. $=0.332$ & 1200 & $20^{\circ}$ & 1 \\
\hline
\end{tabular}

\section{3-1-4- The specific consumed energy:}

Fig. (6) shows that the specific consumed energy (kwh/ton) increased with increasing the cutting drum speed, knife edge angle and clearance distance. It increase by an average $56.1 \%$ with increasing the cutting drum speed from 1200 to $1600 \mathrm{rpm}$ at $20^{\circ}$ knife edge angle, $1 \mathrm{~mm}$ clearance distance and $20.56 \% \mathrm{M}_{\mathrm{cwb}}$. It, also, increased by an average $79.86 \%$ with increasing the knife edge angle from $20^{\circ}$ to $40^{\circ}$ at $1600 \mathrm{rpm}$ cutting drum speed, $1 \mathrm{~mm}$ clearance distance. In general, The specific consumed energy, also, increased slightly by increasing the clearance distance. It increased by an average $3.4 \%$ with increasing the clearance distance from $1 \mathrm{~mm}$ to $5 \mathrm{~mm}$ at $20^{\circ}$ knife edge angle and $1600 \mathrm{rpm}$ cutting drum speed. The maximum and minimum specific consumed energy are given in table (4).

Table (4): Max. and Min. specific consumed energy, for cotton stalks.

\begin{tabular}{|l|c|c|c|}
\hline \multirow{2}{*}{$\begin{array}{c}\text { Specific consumed } \\
\text { energy (kWh/ton) }\end{array}$} & $\begin{array}{c}|c| \\
\text { Cutting drum } \\
\text { speed (rpm) }\end{array}$ & $\begin{array}{c}\text { Knife edge } \\
\text { angle }\end{array}$ & $\begin{array}{c}\text { Clearance } \\
\text { distance (mm) }\end{array}$ \\
\cline { 2 - 4 } Max. $=41.89$ & 1600 & $40^{\circ}$ & 5 \\
\hline Min. $=9.48$ & 1200 & $20^{\circ}$ & 1 \\
\hline
\end{tabular}



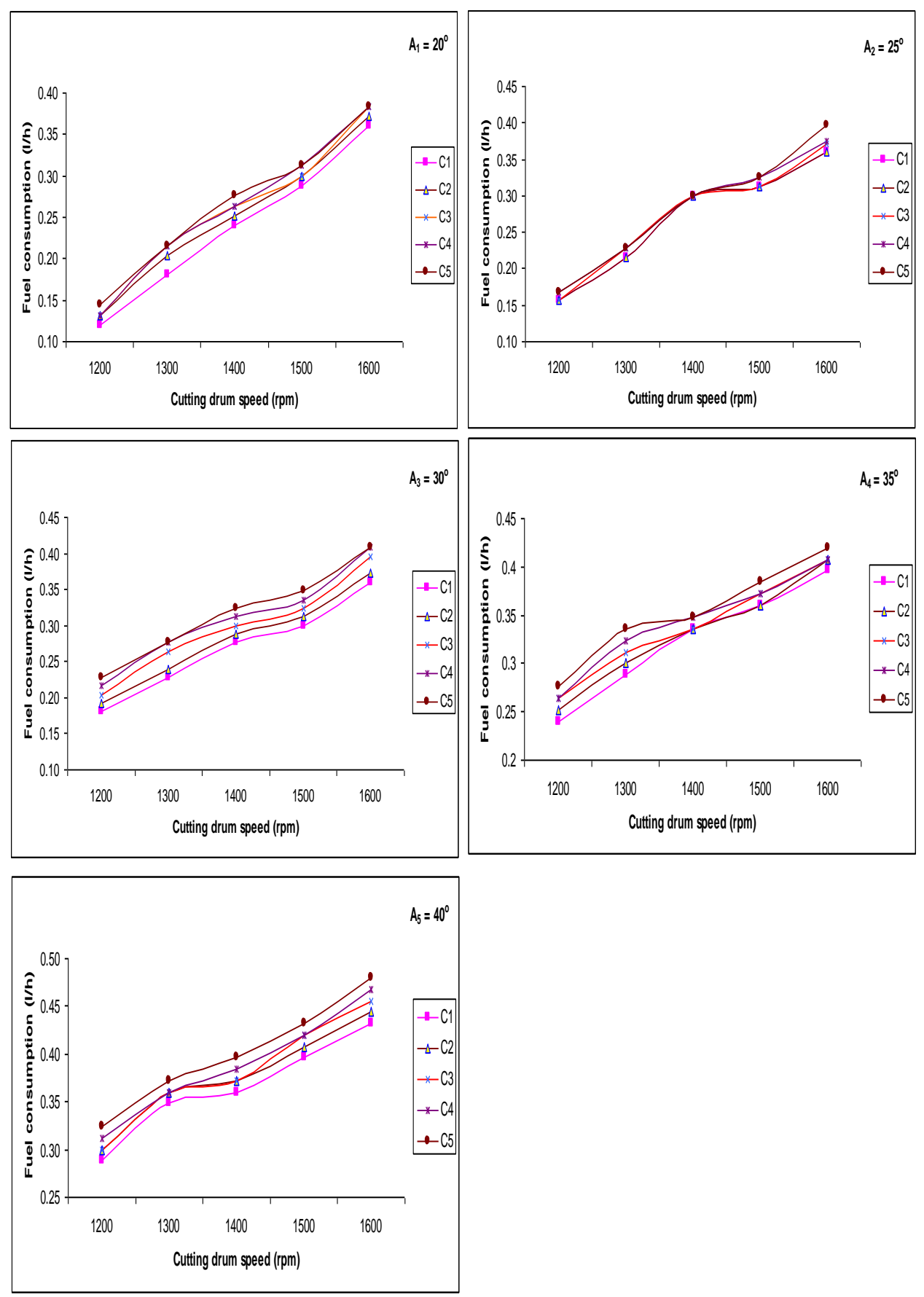

Fig (4): Fuel consumption as a function of cutting drum speed at different (A) knife edge angle $\left(20^{\circ}, 25^{\circ}, 30^{\circ}, 35^{\circ}\right.$ and $\left.40^{\circ}\right)$, (C) clearance distance $(1,2,3,4$, and $5 \mathrm{~mm})$, and $20.56 \% \mathrm{M}_{\mathrm{cwb}}$ for cotton stalks. 
FARM MACHINERY AND POWER
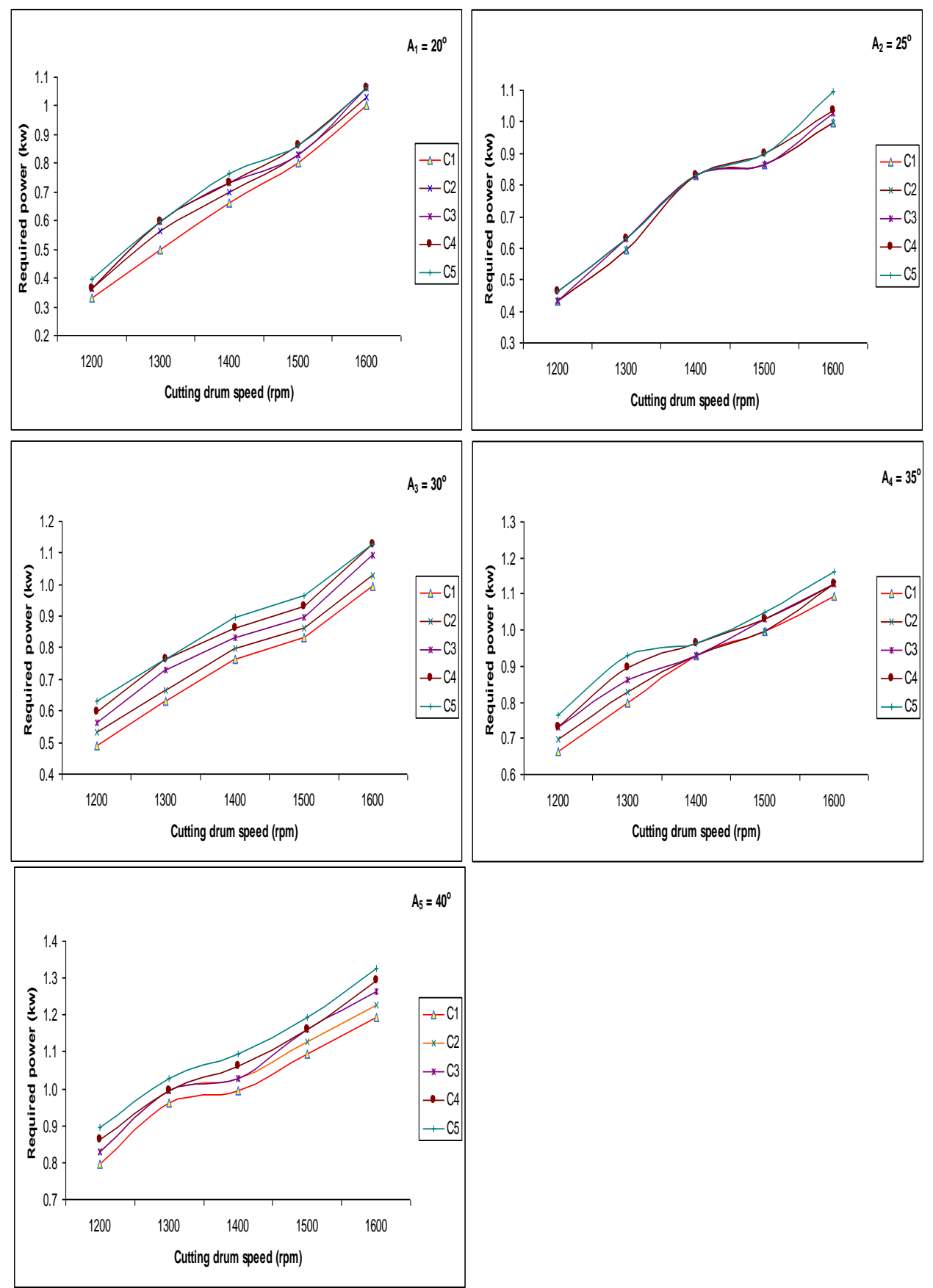

Fig. (5): The required power as a function of cutting drum speed at different (A) knife edge angle $\left(20^{\circ}, 25^{\circ}, 30^{\circ}, 35^{\circ}\right.$ and $\left.40^{\circ}\right)$, (C) clearance distance $(1,2,3,4$, and $5 \mathrm{~mm})$, and $20.56 \% \mathrm{M}_{\mathrm{cwb}}$ for cotton stalks. 

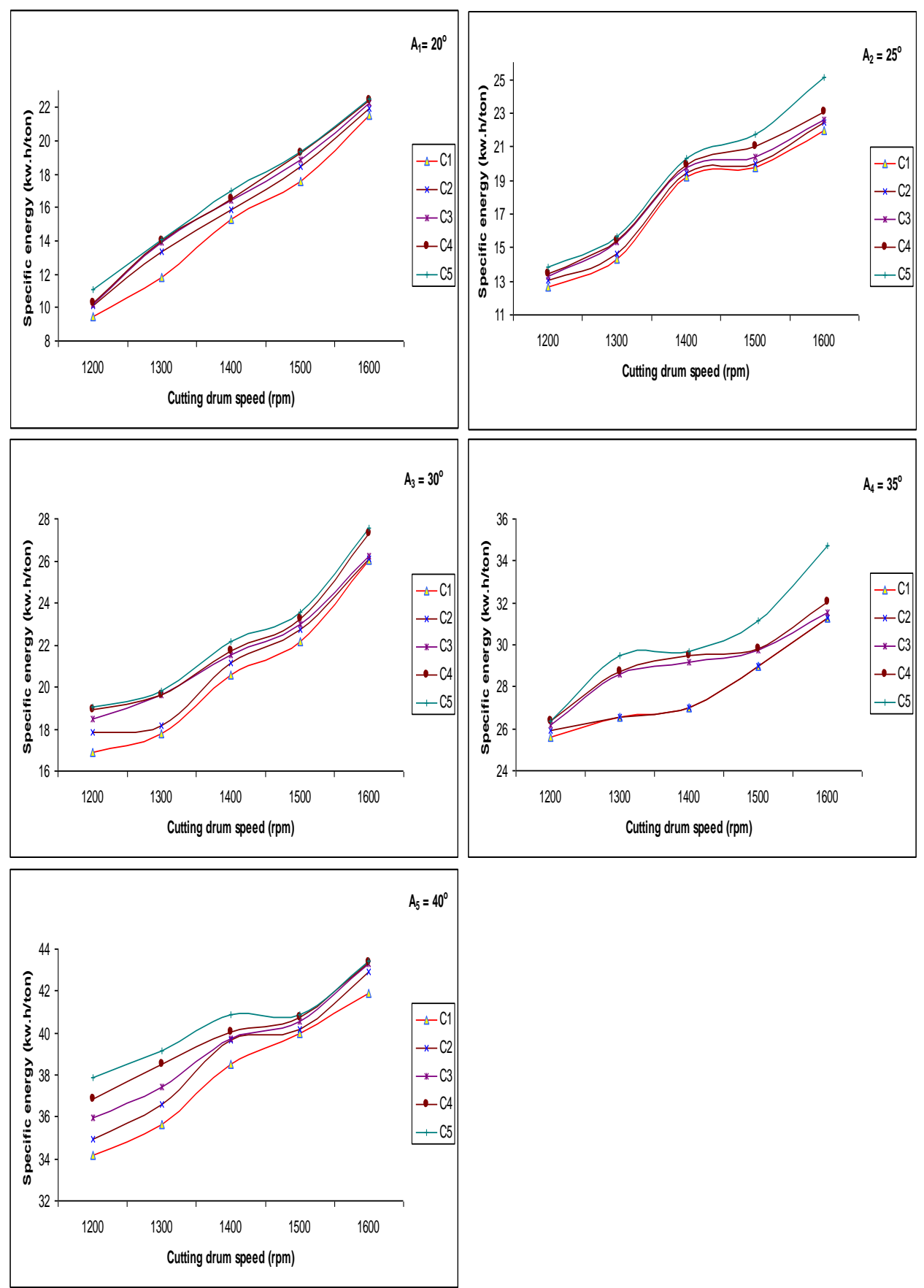

Fig. (6): The specific consumed energy as a function of cutting drum speed at different (A) knife edge angle $\left(20^{\circ}, 25^{\circ}, 30^{\circ}, 35^{\circ}\right.$ and $\left.40^{\circ}\right)$, (C) clearance distance $(1,2,3,4$, and $5 \mathrm{~mm})$, and $20.56 \% \mathrm{M}_{\mathrm{cwb}}$ for cotton stalks. 


\section{3-1-5- Cutting efficiency:}

The relation between cutting efficiency and cutting drum speed at different knife edge angle $\left(20^{\circ}, 25^{\circ}, 30^{\circ}, 35^{\circ}\right.$ and $\left.40^{\circ}\right)$, clearance distance $(1,2,3,4$, and $5 \mathrm{~mm})$ and $20.56 \% \mathrm{M}_{\mathrm{cwb}}$ is shown in Fig. (7). It is clear that the cutting efficiency increased with increasing the cutting drum speed. It increased by an average $23.6 \%$ with increasing the cutting drum speed from 1200 to $1600 \mathrm{rpm}$ at $20^{\circ}$ knife edge angle, and $1 \mathrm{~mm}$ clearance distance. Such increase was due to the increase in the number of cuts per unit time which increased the weight of suitable cutting length, less than $5 \mathrm{~mm}$ (Sluliman et. al., 2010).

It can be, also, noticed that the cutting efficiency decreased with increasing the knife edge angle. The cutting efficiency decreased by an average $41.82 \%$ with increasing the knife edge angle from $20^{\circ}$ to $40^{\circ}$ at $1600 \mathrm{rpm}$ cutting drum speed and $1 \mathrm{~mm}$ clearance distance. It is, also, obvious that the cutting efficiency decreased with increasing the clearance distance. It decreased by an average $11.12 \%$ with increasing the clearance distance from 1 to $5 \mathrm{~mm}$ at $20^{\circ}$ knife edge angle, and $1600 \mathrm{rpm}$ cutting drum speed. The maximum and minimum cutting efficiency are given in table (5).

Table (5) : Max. and Min. cutting efficiency for cotton stalks.

\begin{tabular}{|c|c|c|c|}
\hline \multirow{2}{*}{$\begin{array}{c}\text { Cutting efficiency } \\
(\%)\end{array}$} & \multicolumn{3}{|c|}{ Engineering factors } \\
\hline & $\begin{array}{l}\text { Cutting drum } \\
\text { speed (rpm) }\end{array}$ & $\begin{array}{c}\text { Knife edge } \\
\text { angle }\end{array}$ & $\begin{array}{c}\text { Clearance } \\
\text { distance }(\mathrm{mm})\end{array}$ \\
\hline Max. $=67.70$ & 1600 & $20^{\circ}$ & 1 \\
\hline Min. $=24.91$ & 1200 & $40^{\circ}$ & 5 \\
\hline
\end{tabular}

\section{3-1-6- Cost estimation:}

The cost per hour of operation of the cutting machine is estimated using equation (7) at the best cutting efficiency (67.7\%) where the fuel consumption $=0.36 \mathrm{l} / \mathrm{h}$, and the productivity $=0.0462 \mathrm{ton} / \mathrm{h}$

Cost $=6.94$ L.E. $/ \mathrm{h}$

Or cost $=(6.94 L E / h) / 0.0462=150.23$ LE $/$ Ton 

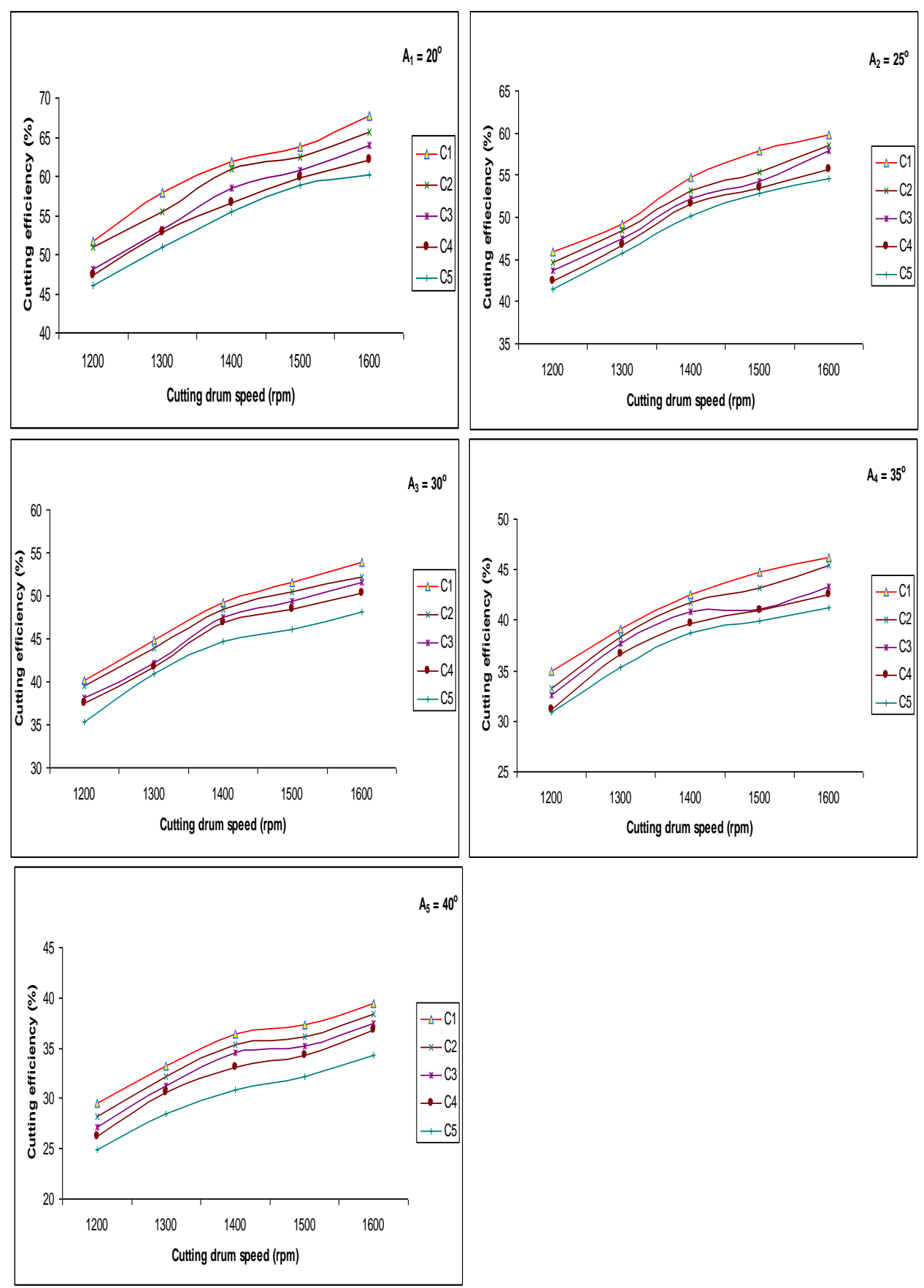

Fig. (7): Cutting efficiency as a function of cutting drum speed at different (A) knife edge angle $\left(20^{\circ}, 25^{\circ}, 30^{\circ}, 35^{\circ}\right.$ and $\left.40^{\circ}\right)$, (C) clearance distance $(1,2,3,4$, and $5 \mathrm{~mm})$, and $20.56 \% \mathrm{M}_{\mathrm{cwb}}$ for cotton stalks. 
Data for corn stalks and rice straw show similar trend to that obtained previously for cotton stalks, so the main results would be presented next:-

\section{3-2- Corn stalks}

Results for corn stalks (25.64\% $\mathrm{M}_{\mathrm{cwb}}$ ) showed that:-

\section{3-2-1- Machine Productivity:}

Machine productivity increased by an average $34.66 \%$ with increasing the cutting drum speed from 1200 to $1600 \mathrm{rpm}$, at $20^{\circ} \mathrm{knife}$ edge angle, $1 \mathrm{~mm}$ clearance distance, and $25.64 \% \mathrm{M}_{\mathrm{cwb}}$. They, also, show that productivity decreased with an average $31.72 \%$ with increasing the knife edge angle from $20^{\circ}$ to $40^{\circ}$ at $1600 \mathrm{rpm}$ cutting drum speed and $1 \mathrm{~mm}$ clearance distance. It can be also noticed that there was slight increase of the machine productivity with increasing the clearance distance. It increased by an average $4.60 \%$ with increasing the clearance distance from 1 to $5 \mathrm{~mm}$ at $1600 \mathrm{rpm}$ cutting drum speed, $20^{\circ} \mathrm{knife}$ edge angle, and $25.64 \%$ $\mathrm{M}_{\mathrm{cwb}}$. Maximum and minimum rate of machine productivity at $25.64 \%$ $\mathbf{M}_{\mathrm{cwb}}$ are given in Table (6).

Table (6): Max. and Min. rate of machine productivity, for corn stalks.

\begin{tabular}{|c|c|c|c|}
\hline \multirow{2}{*}{$\begin{array}{l}\text { Productivity } \\
\quad(\text { ton/h) }\end{array}$} & \multicolumn{3}{|c|}{ Engineering factors } \\
\hline & $\begin{array}{l}\text { Cutting drum } \\
\text { speed (rpm) }\end{array}$ & $\begin{array}{c}\text { Knife edge } \\
\text { angle }\end{array}$ & $\begin{array}{c}\text { Clearance } \\
\text { distance }(\mathrm{mm})\end{array}$ \\
\hline Max. $=0.0499$ & 1600 & $20^{\circ}$ & 5 \\
\hline Min. $=0.0175$ & 1200 & $40^{\circ}$ & 1 \\
\hline
\end{tabular}

\section{3-2-2- Fuel consumption:}

Fuel consumption increased by an average $52.17 \%$ with increasing the cutting drum speed from 1200 to $1600 \mathrm{rpm}$ at $20^{\circ} \mathrm{knife}$ edge angle, $1 \mathrm{~mm}$ clearance distance, and $25.64 \% \mathrm{M}_{\mathrm{cwb}}$. It is also clear that fuel consumption increased with increasing knife edge angle. It increased by an average $39.47 \%$ with increasing knife edge angle from $20^{\circ}$ to $40^{\circ}$ at $1600 \mathrm{rpm}$ cutting drum speed, $1 \mathrm{~mm}$ clearance distance, and $25.64 \mathrm{M}_{\text {cub. }}$. This may be due to increasing the friction forces (main resistance for cutting) on the knife edge with increasing the knife edge angle. Results also, showed that full consumption increased slightly with increasing the clearance distance. It increased by an average $14.81 \%$ with increasing the 
clearance distance from 1 to $5 \mathrm{~mm}$ at $20^{\circ} \mathrm{knife}$ edge angle, $1600 \mathrm{rpm}$ cutting drum speed, and $25.64 \% \mathrm{M}_{\mathrm{cwb}}$.

The maximum and minimum rates of fuel consumption are given in table (7).

Table (7): Max. and Min. rate of fuel consumption, for corn stalks.

\begin{tabular}{|c|c|c|c|}
\hline \multirow{2}{*}{$\begin{array}{c}\text { Fuel } \\
\text { consumption } \\
(\mathrm{L} / \mathrm{h})\end{array}$} & $\begin{array}{c}\mid 3 \\
\text { Cutting drum } \\
\text { speed (rpm) }\end{array}$ & $\begin{array}{c}\text { Knife edge } \\
\text { angle }\end{array}$ & $\begin{array}{c}\text { Clearance } \\
\text { distance }(\mathrm{mm})\end{array}$ \\
\cline { 2 - 4 } & 1600 & $40^{\circ}$ & 5 \\
\hline Max. $=0.504$ & 1200 & $20^{\circ}$ & 1 \\
\hline
\end{tabular}

\section{3-2-3- The required power:}

The required power increased by an average $42.37 \%$ with increasing the cutting drum speed from 1200 to $1600 \mathrm{rpm}$ at $30^{\circ} \mathrm{knife}$ edge angle, $1 \mathrm{~mm}$ clearance distance, and $25.64 \% \mathrm{M}_{\mathrm{cwb}}$. It, also, increased by an average $45.18 \%$ with increasing the knife edge angle from $20^{\circ}$ to $40^{\circ}$ at $1400 \mathrm{rpm}$ cutting drum speed, and $1 \mathrm{~mm}$ clearance distance. The required power increased slightly by an average $14.84 \%$ with increasing the clearance distance from 1 to $5 \mathrm{~mm}$ at $20^{\circ} \mathrm{knife}$ edge angle and $1600 \mathrm{rpm}$. Maximum and minimum required power are given in Table (8).

Table (8) : Max. and Min. required power, for corn stalks

\begin{tabular}{|l|c|c|c|}
\hline \multirow{2}{*}{$\begin{array}{c}\text { Required Power } \\
(\mathrm{kW})\end{array}$} & $\begin{array}{c}\text { Eutting drum } \\
\text { speed (rpm) }\end{array}$ & $\begin{array}{c}\text { Knife edge } \\
\text { angle }\end{array}$ & $\begin{array}{c}\text { Clearance } \\
\text { distance }(\mathrm{mm})\end{array}$ \\
\cline { 2 - 4 } & 1600 & $40^{\circ}$ & 5 \\
\hline Max. = 1.394 & 1200 & $20^{\circ}$ & 1 \\
\hline Min. = 0.365 & & & \\
\hline
\end{tabular}

\section{3-2-4- The specific consumed energy:}

The specific consumed energy (kWh/ton) increased by an average $26.77 \%$ with increasing the cutting drum speed from 1200 to $1600 \mathrm{rpm}$ at $20^{\circ}$ knife edge angle, $1 \mathrm{~mm}$ clearance distance and $25.64 \% \mathrm{M}_{\mathrm{cwb}}$. It, also, increased by an average $58.74 \%$ with increasing the knife edge angle from $20^{\circ}$ to $40^{\circ}$ at $1600 \mathrm{rpm}$ cutting drum speed, $1 \mathrm{~mm}$ clearance distance. In general the specific consumed energy, also, increased slightly by increasing the clearance distance. It increased by an average $10.75 \%$ with 
increasing the clearance distance from $1 \mathrm{~mm}$ to $5 \mathrm{~mm}$ at $20^{\circ}$ knife edge angle and $1600 \mathrm{rpm}$ cutting drum speed. The maximum and minimum specific consumed energy are given in table (9).

Table (9) Max. and Min. specific consumed energy, for corn stalks.

\begin{tabular}{|l|c|c|c|}
\hline \multirow{2}{*}{\begin{tabular}{c}
\multirow{2}{*}{$\begin{array}{c}\text { Specific } \\
\text { consumed } \\
\text { energy (kWh/ton) }\end{array}$} \\
\cline { 2 - 4 }
\end{tabular}} & $\begin{array}{c}\text { Cutting drum } \\
\text { speed (rpm) }\end{array}$ & $\begin{array}{c}\text { Knife edge } \\
\text { angle }\end{array}$ & $\begin{array}{c}\text { Clearance } \\
\text { distance (mm) }\end{array}$ \\
\hline Max. = 47.64 & 1600 & $40^{\circ}$ & 5 \\
\hline Min. = 11.73 & 1200 & $20^{\circ}$ & 1 \\
\hline
\end{tabular}

\section{3-2-5- Cutting efficiency:}

The cutting efficiency increased by an average $12.46 \%$ with increasing the cutting drum speed from 1200 to $1600 \mathrm{rpm}$ at $20^{\circ}$ knife edge angle, and $1 \mathrm{~mm}$ clearance distance. It can be also noticed that the cutting efficiency decreased with increasing the knife edge angle. The cutting efficiency decreased by an average $42.52 \%$ with increasing the knife edge angle from $20^{\circ}$ to $40^{\circ}$ at $1600 \mathrm{rpm}$ cutting drum speed and $1 \mathrm{~mm}$ clearance distance. It is, also, obvious that the cutting efficiency decreased with increasing the clearance distance. It decreased by an average $9.22 \%$ with increasing the clearance distance from 1 to $5 \mathrm{~mm}$ at $20^{\circ} \mathrm{knife}$ edge angle, and $1600 \mathrm{rpm}$ cutting drum speed. The maximum and minimum cutting efficiency are given in table (10).

Table (10) : Max. and Min. cutting efficiency for corn stalks.

\begin{tabular}{|c|c|c|c|}
\hline \multirow{2}{*}{$\begin{array}{c}\text { Cutting } \\
\text { efficiency }(\%)\end{array}$} & \multicolumn{3}{|c|}{ Engineering factors } \\
\hline & $\begin{array}{c}\text { Cutting drum } \\
\text { speed (rpm) }\end{array}$ & $\begin{array}{c}\text { Knife edge } \\
\text { angle }\end{array}$ & $\begin{array}{c}\text { Clearance } \\
\text { distance }(\mathrm{mm})\end{array}$ \\
\hline Max. $=47.59$ & 1600 & $20^{\circ}$ & 1 \\
\hline Min. $=17.88$ & 1200 & $40^{\circ}$ & 5 \\
\hline
\end{tabular}

\section{3-2-6- Cost estimation:}

The cost per hour of operation of the cutting machine is estimated using equation (7) at the best cutting efficiency (47.59\%) where the fuel consumption $=0.276 \mathrm{l} / \mathrm{h}$, and the productivity $=0.0476 \mathrm{ton} / \mathrm{h}$

Cost $=6.83$ L.E. $/ \mathrm{h}$

Or cost $=(6.83 L E / h) / 0.0462=147.83 L E /$ Ton 


\section{3-3- Rice Stalks}

The obtained results for rice straw showed that:-

\section{3-3-1- Machine Productivity:}

Machine productivity increased by an average $9.09 \%$ with increasing the cutting drum speed from 1200 to $1600 \mathrm{rpm}$, at $20^{\circ} \mathrm{knife}$ edge angle, $1 \mathrm{~mm}$ clearance distance, and $14.8 \% \mathrm{M}_{\mathrm{cwb}}$. They, also, show that productivity decreased with an average $48.18 \%$ with increasing the knife edge angle from $20^{\circ}$ to $40^{\circ}$ at $1600 \mathrm{rpm}$ cutting drum speed and $1 \mathrm{~mm}$ clearance distance. It can be, also, noticed that there was slight increase of the machine productivity with increasing the clearance distance. It increased by an average $7.56 \%$ with increasing the clearance distance from 1 to $5 \mathrm{~mm}$ at $1600 \mathrm{rpm}$ cutting drum speed, $20^{\circ}$ knife edge angle, and $14.8 \%$ $\mathrm{M}_{\mathrm{cwb}}$. Maximum and minimum rate of machine productivity at $14.8 \%$ $\mathbf{M}_{\mathrm{cwb}}$ are given in Table (11).

Table (11): Max. and Min. rate of machine productivity, for rice stalks.

\begin{tabular}{|c|c|c|c|}
\hline \multirow{2}{*}{$\begin{array}{c}\text { Productivity } \\
(\text { ton} / \mathrm{h})\end{array}$} & $\begin{array}{c}\mid 3 \\
\text { Cutting drum } \\
\text { speed (rpm) }\end{array}$ & $\begin{array}{c}\text { Knife edge } \\
\text { angle }\end{array}$ & $\begin{array}{c}\text { Clearance } \\
\text { distance }(\mathrm{mm})\end{array}$ \\
\hline Max. $=0.0595$ & 1600 & $20^{\circ}$ & 5 \\
\hline Min. $=0.0240$ & 1200 & $40^{\circ}$ & 1 \\
\hline
\end{tabular}

\section{3-3-2- Fuel consumption:}

Fuel consumption increased by an average $66.66 \%$ with increasing the cutting drum speed from 1200 to $1600 \mathrm{rpm}$ at $20^{\circ} \mathrm{knife}$ edge angle, $1 \mathrm{~mm}$ clearance distance, and $14.8 \% \mathrm{M}_{\mathrm{cwb}}$. It is also clear that fuel consumption increased with increasing knife edge angle. It increased by an average $36.17 \%$ with increasing knife edge angle from $20^{\circ}$ to $40^{\circ}$ at $1600 \mathrm{rpm}$ cutting drum speed, $1 \mathrm{~mm}$ clearance distance, and $14.8 \% \mathrm{M}_{\text {cub. }}$ This may be due to increasing the friction forces (main resistance for cutting) on the knife edge with increasing the knife edge angle. Results also, showed that full consumption increased slightly with increasing the clearance distance. It increased by an average $9.09 \%$ with increasing the clearance distance from 1 to $5 \mathrm{~mm}$ at $20^{\circ} \mathrm{knife}$ edge angle, $1600 \mathrm{rpm}$ cutting drum speed, and $14.8 \% \mathrm{M}_{\mathrm{cwb}}$. 
The maximum and minimum rate of fuel consumption are given in table (12)

Table (12): Max. and Min. rate of fuel consumption for rice stalks.

\begin{tabular}{|l|c|c|c|}
\hline \multirow{2}{*}{$\begin{array}{c}\text { Fuel } \\
\text { consumption } \\
(\mathrm{L} / \mathrm{h})\end{array}$} & $\begin{array}{c}|c| \\
\text { Cutting drum } \\
\text { speed (rpm) }\end{array}$ & $\begin{array}{c}\text { Knife edge } \\
\text { angle }\end{array}$ & $\begin{array}{c}\text { Clearance } \\
\text { distance (mm) }\end{array}$ \\
\cline { 2 - 4 } Max. $=0.624$ & 1600 & $40^{\circ}$ & 5 \\
\hline Min. $=0.12$ & 1200 & $20^{\circ}$ & 1 \\
\hline
\end{tabular}

\section{3-3-3- The required power:}

The required power increased by an average $53.89 \%$ with increasing the cutting drum speed from 1200 to $1600 \mathrm{rpm}$ at $30^{\circ} \mathrm{knife}$ edge angle, $1 \mathrm{~mm}$ clearance distance, and $14.8 \% \mathrm{M}_{\mathrm{cwb}}$. It, also, increased by an average $44.43 \%$ with increasing the knife edge angle from $20^{\circ}$ to $40^{\circ}$ at $1400 \mathrm{rpm}$ cutting drum speed, and $1 \mathrm{~mm}$ clearance distance. The required power increased slightly by an average $9.04 \%$ with increasing the clearance distance from 1 to $5 \mathrm{~mm}$ at $20^{\circ} \mathrm{knife}$ edge angle and $1600 \mathrm{rpm}$. maximum and minimum required power are given in Table (13).

Table (13): Max. and Min. required power, for rice stalks.

\begin{tabular}{|l|c|c|c|}
\hline \multirow{2}{*}{$\begin{array}{c}\text { Required Power } \\
(\mathrm{kW})\end{array}$} & $\begin{array}{c}\text { Eutting drum } \\
\text { speed (rpm) }\end{array}$ & $\begin{array}{c}\text { Knife edge } \\
\text { angle }\end{array}$ & $\begin{array}{c}\text { Clearance } \\
\text { distance }(\mathrm{mm})\end{array}$ \\
\cline { 2 - 4 } Max. = 1.726 & 1600 & $40^{\circ}$ & 5 \\
\hline Min. $=0.332$ & 1200 & $20^{\circ}$ & 1 \\
\hline
\end{tabular}

\section{3-3-4- The specific consumed energy:}

The specific consumed energy ( $\mathrm{kWh} /$ ton) increase by an average $63.31 \%$ with increasing the cutting drum speed from 1200 to $1600 \mathrm{rpm}$ at $20^{\circ}$ knife edge angle, $1 \mathrm{~mm}$ clearance distance and $14.8 \% \mathrm{M}_{\mathrm{cwb}}$. It, also, increased by an average $66.92 \%$ with increasing the knife edge angle from $20^{\circ}$ to $40^{\circ}$ at $1600 \mathrm{rpm}$ cutting drum speed, $1 \mathrm{~mm}$ clearance distance. In general, the specific consumed energy, also, increased slightly by increasing the clearance distance. It increased by an average $1.63 \%$ with increasing the clearance distance from $1 \mathrm{~mm}$ to $5 \mathrm{~mm}$ at $20^{\circ}$ knife edge 
angle and $1600 \mathrm{rpm}$ cutting drum speed. The maximum and minimum specific consumed energy are given in table (14).

Table (14): Max. and Min. specific consumed energy, for rice stalks.

\begin{tabular}{|c|c|c|c|}
\hline \multirow{2}{*}{$\begin{array}{c}\text { Specific } \\
\text { consumed } \\
\text { energy }(\mathrm{kWh} / \mathrm{ton})\end{array}$} & \multicolumn{3}{|c|}{ Engineering factors } \\
\hline & $\begin{array}{l}\text { Cutting drum } \\
\text { speed (rpm) }\end{array}$ & $\begin{array}{l}\text { Knife edge } \\
\text { angle }\end{array}$ & $\begin{array}{c}\text { Clearance } \\
\text { distance }(\mathrm{mm})\end{array}$ \\
\hline Max. $=54.73$ & 1600 & $40^{\circ}$ & 5 \\
\hline Min. $=6.64$ & 1200 & $20^{\circ}$ & 1 \\
\hline
\end{tabular}

\section{3-3-5- Cutting efficiency:}

The cutting efficiency increased by an average $27.25 \%$ with increasing the cutting drum speed from 1200 to $1600 \mathrm{rpm}$ at $20^{\circ}$ knife edge angle, and $1 \mathrm{~mm}$ clearance distance.

It can be also noticed that the cutting efficiency decreased with increasing the knife edge angle. The cutting efficiency decreased by an average $37.14 \%$ with increasing the knife edge angle from $20^{\circ}$ to $40^{\circ}$ at $1600 \mathrm{rpm}$ cutting drum speed and $1 \mathrm{~mm}$ clearance distance. It is, also, obvious that the cutting efficiency decreased with increasing the clearance distance. It decreased by an average $8.58 \%$ with increasing the clearance distance from 1 to $5 \mathrm{~mm}$ at $20^{\circ} \mathrm{knife}$ edge angle, and $1600 \mathrm{rpm}$ cutting drum speed. The maximum and minimum cutting efficiency are given in table (15).

Table (15): Max. and Min. cutting efficiency for rice stalks.

\begin{tabular}{|l|c|c|c|}
\hline \multirow{2}{*}{$\begin{array}{c}\text { Cutting } \\
\text { efficiency } \\
(\%)\end{array}$} & $\begin{array}{c}\text { Cutting drum } \\
\text { speed (rpm) }\end{array}$ & $\begin{array}{c}\text { Knife edge } \\
\text { angle }\end{array}$ & $\begin{array}{c}\text { Clearance } \\
\text { distance }(\mathrm{mm})\end{array}$ \\
\cline { 2 - 4 } & 1600 & $20^{\circ}$ & 1 \\
\hline Max. =62.75 & 1200 & $40^{\circ}$ & 5 \\
\hline Min. = 20.92 & \multicolumn{3}{|c|}{} \\
\hline
\end{tabular}

\section{3-3-6- Cost estimation:}

The cost per hour of operation of the cutting machine is estimated using equation (7) at the best cutting efficiency $(62.75 \%)$ where the fuel consumption $=0.36 \mathrm{l} / \mathrm{h}$, and the productivity $=0.0550 \mathrm{ton} / \mathrm{h}$

$$
\begin{aligned}
& \text { Cost }=6.94 \text { L.E. } / \mathrm{h} \\
& \text { Or cost }=(6.94 L E / h) / 0.0462=150.23 \text { LE } / \text { Ton }
\end{aligned}
$$




\section{CONCLUSION}

The performance of an experimental crop residues cutting machine is evaluated to determine the energy requirements for cutting operation of three different crop residues (cotton stalks, corn stalks and rice straw). The effect of cutting drum speed, knife edge angle, and clearance distance on the machine productivity, fuel consumption, required power, specific consumed energy, cutting efficiency and the estimated cost of machine operation were, also, discussed. The machine evaluated at five cutting drum speeds $1200,1300,1400,1500$ and $1600 \mathrm{rpm}(8.29,8.98,9.3 .68$, 10.37 and $11.06 \mathrm{~m} / \mathrm{s})$; five knife edge angle $\left(20^{\circ}, 25^{\circ}, 30^{\circ}, 35^{\circ}\right.$ and $\left.40^{\circ}\right)$, and five clearance distance (1, 2, 3, 4 and 5mm). The results, at $1600 \mathrm{rpm}$ cutting drum speed, $20^{\circ}$ knife edge angle and $1 \mathrm{~mm}$ clearance distance, showed that the machine productivity, fuel consumption, required power, specific consumed energy, maximum cutting efficiency and estimated cost of machine operation were:

- for cotton stalks (20.56\% Mcwb): 0.0476 ton $/ \mathrm{h}, 0.48 \mathrm{~L} / \mathrm{h}, 1.328 \mathrm{kw}$, $41.89 \mathrm{kwh} / \mathrm{ton}, 67.70 \%$, and 150.23 LE/ton, respectively;

- for corn stalks $(25.64 \% \mathrm{Mcwb}): 0.0499 \mathrm{ton} / \mathrm{h}, 0.504 \mathrm{l} / \mathrm{h}, 1.394 \mathrm{kw}$, $47.64 \mathrm{kwh} / \mathrm{ton}, 47.59 \%$ and $147.83 \mathrm{LE} / \mathrm{ton}$, respectively; and

- for rice straw (14.8\% Mcwb): 0.0595 ton/h,0.624 L/h, $1.726 \mathrm{kw}, 54.73$ $\mathrm{kwh} / \mathrm{ton}, 62.75 \%$, and $150.23 \mathrm{LE} / \mathrm{ton}$, respectively.

\section{REFERENCE}

Awady, M.N.; M. Shaaban; I. Yehia and M.S. Mira (2001). Review on equipment industry for agricultural-residues management in Egypt. Misr. J. Agric. Eng., 18 (4):96-108.

El-Awady, M.N. (1978). Engineering of tractors and agricultural machinery, tex Bk., Col. Agric. Ain-Shams Univ.

El-Berry, A.M.; M.A. Baiomy; H.A. Radwan and E.M. Arif. (2001). Evaulation of (Hematol) machine in rice straw chopping. Misr. J. Agric. Eng., 18(4):65-76.

El-Hanfy, E.H. and S.A. Shalby, (2009). Performance Evaluation and Modification of the Japanese combine chopping Unit. Misr J. Agric. Eng., 26 (2) : 1021-1035. 
Embaby, A.T. (1985). A comparison of the different mechanization systems of cereal crop production. M.Sc. Thesis Agric. Eng., Cair Univ.

Habib, R.A.; Azzam, B.S.; Nasr, G.M. and Khattab, A.A. (2002). The parameters affecting the cutting process performance of agricultural plants. Misr J. Agr. Eng. 19 (2): 361-372.

Henderson,S.M. and R.L. Perry (1981). Food process engineering. $2^{\text {nd }}$ ed. AVI publishing company Inc., Westport, Connecticut, USA: 66.

Suliman; S. Ahmed and A. Ramdan (2010). Study of some Engineering factors concerning the performance of the affecting tool in crop resiues shredder p. 1555-1571.

Taieb, A.E. and A.T. Imbabi (1995). Energy Requirements for the cutting operation of some crops. Misr J., Agric. ENg., 12 (2) : 510526.

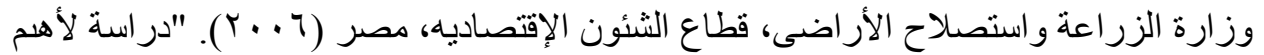

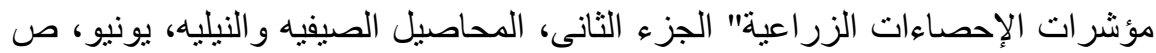

\section{الملخص العربي \\ الطاقه المطلوبه لعملية قطع مخلفات بعض محاصيل الحقل

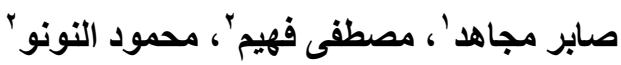

معظم مخلفات المحاصيل الزراعية تكون ناتجه عن عمليات الحصـاد. و هنـاك كميات هائلة من

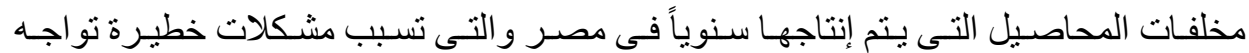
المنتجين الزر اعيين. وتعتبر عملية تقطيع مخلفات المحصول لقطع صغيرة طريقه فعاله وبسيطه لكى تكون مناسبة للتخزين و التداول و التدوير لكى تتناسب ميع الاستخدامات العديدة. وفى هذه الدر اسة تم تقييم اداء ماكينة تجرييية لتقطيع مخلفات المحاصيل لتحديد الطاقة المطلوبـة لعملية القطع لثلاث مخلفات محاصيل وهى (حطب القطن - سيقان الذرة - وقش الأرز) كمـا تمت الته مناقثة تأثير السر عة الدور انيه لإسطو انة السكاكين وز اوية حافة سكين القطع ومسافة الخلوص، إنتاجية الألة، استهلاك الوقود، القدره المطلوبة، الطاقه النوعيه المستهلكه، كفاءة القطع، وتكلفة

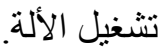

\footnotetext{
' طالب دراسات عليا ـ كلية الزراعة - جامعة عين شمس.

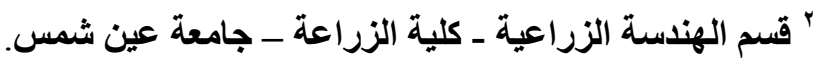




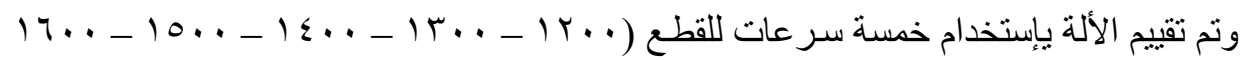

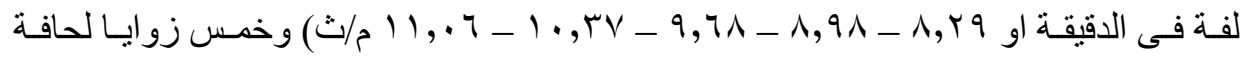

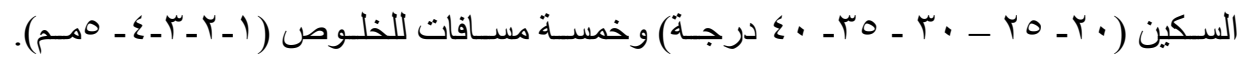

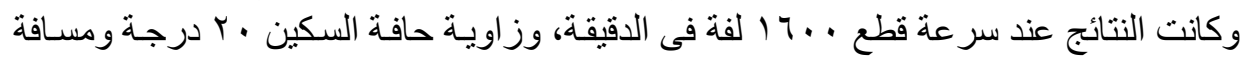

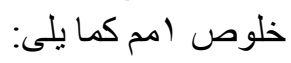

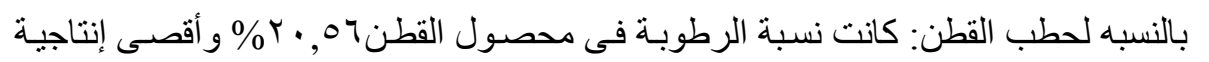

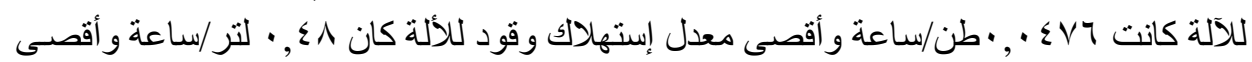

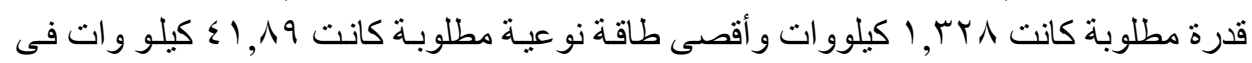

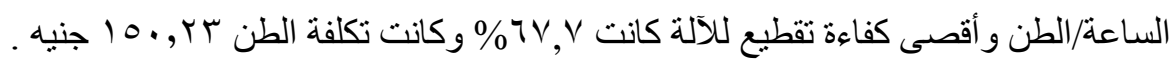

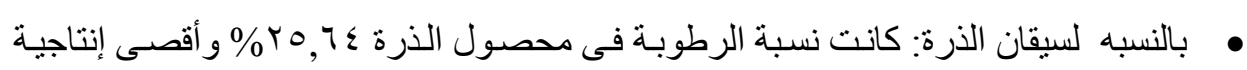

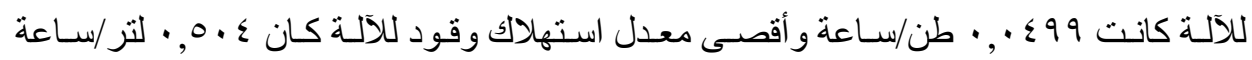

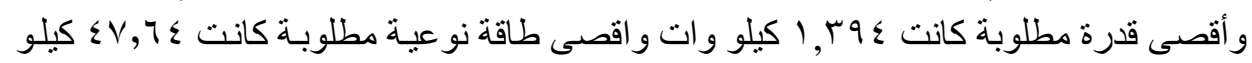

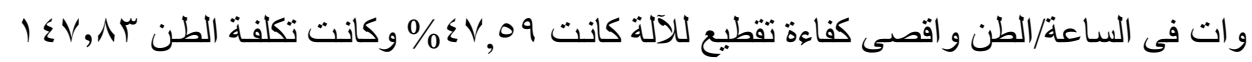
جنيه.

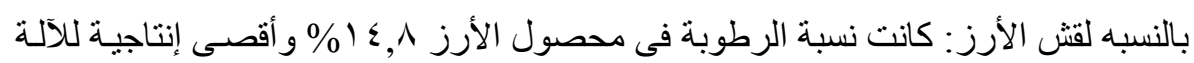

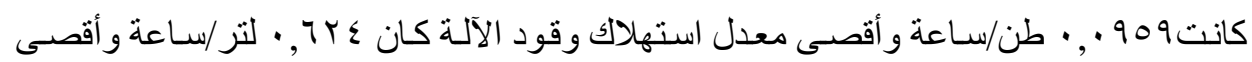

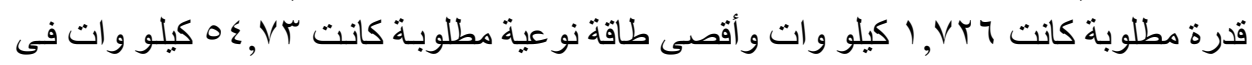

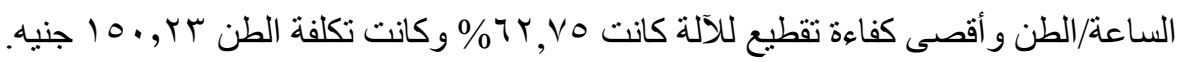

